\title{
Effect of Prosthodontic Rehabilitation on Perioral Units in Edentulous Patients
}

\author{
Hakkı Çelebi(0000-0001-8349-1076) ${ }^{\alpha}$, Raif Alan(0000-0003-2602-3481) ${ }^{\beta}$, Elif Kartal(0000-0001-7442-1535) ${ }^{\gamma}$ \\ Selcuk Dent J, 2021; 8: 648-651 (Doi: 10.15311/selcukdentj.748993)
}

Bașvuru Tarihi: 27 Mayıs 2020 Yayına Kabul Tarihi: 09 Eylül 2020

\begin{abstract}
Effect of Prosthodontic Rehabilitation on Perioral Units in Edentulous Patients

Background: Complete edentulous patients experience loss in fundamental mastication functions, the progressive absorption of the alveolar bone, and variation in facial appearance. Complete dentures (CD) fundamentally target edentulous patients and not only increase functionality but also restore the appearance of the face. This study aims to evaluate the effect of rehabilitation with removable $C D$ on perioral wrinkles in complete edentulous patients, in line with growing aesthetic demand.
\end{abstract}

Methods: Patients who had CD rehabilitation performed due to total edentulism were photographed before and after rehabilitation from the same angles to evaluate the perioral soft tissue changes. The photographs were scored using verified ranking scales and through evaluation by two observers. To evaluate the repeatability of the scales, measurements were repeated with the same method one month later.

Results: When the effect of prosthetic rehabilitation administered successfully on perioral aesthetics and lip volume was analyzed, a significant improvement was observed in all other parameters evaluated, except for in the labiomental crease. The improvement in the labiomental crease was not statistically significant. In addition, re-measurement reliability was high $(\geq 0.80)$ for all four perioral units (nasolabial folds, corners of mouth, labiomental crease and upper radial lip). In addition, all correlations were statistically significant $(p<0.05)$.

Conclusion: Rehabilitation with CD contributed positively to the development of the perioral wrinkles and lip volume, which are also observed as a result of edentulism.

\section{KEYWORDS}

Complete denture, Edentulism, Facial appearance, Perioral wrinkles

Facial aging, its effect on face morphology, and surgical correction are among the most debated issues in aesthetic surgery. The special area of interest are the processes of aging for the perioral region. The lips and the surrounding soft tissue play an important role in nonverbal communication and psychological communication while speaking. ${ }^{1,2}$

Ageing is considered a process that inevitably accompanies tooth loss in the long term. Although it is well known that teeth can exist all through life in many öz

Dişsiz Hastalarda Protez Rehabilitasyonunun Perioral Birimler Üzerine Etkisi

Amaç: Tam dişsiz hastalar temel çiğneme fonksiyonlarında kayıp, alveoler kemiğin progresif abzorpsiyonu ve yüz görünümünde değişiklik gösterirler. Tam protezler (TP) temel olarak dişsiz hastaları hedef alır ve sadece işlevselliği arttırmakla kalmaz, aynı zamanda yüz görünümünü de geri kazandııır. Bu çalışmada tam dişsiz hastalarda çıkarılabilir TP ile rehabilitasyonun artan estetik talep doğrultusunda perioral estetik birimler üzerine etkisi araştırıldı.

Gereç ve Yöntemler: Total dişsizlik nedeniyle TP rehabilitasyonu uygulanan hastalar, perioral yumuşak doku değişikliklerini değerlendirmek için rehabilitasyon öncesi ve sonrası aynı açılardan fotoğraflandı. Fotoğraflar, doğrulanmış sıralama ölçekleri kullanılarak ve iki gözlemci tarafından değerlendirilerek puanlandı. Ölçeklerin tekrarlanabilirliğini değerlendirmek için ölçümler bir ay sonra aynı yöntemle tekrarlandı.

Bulgular: Başarılı bir şekilde uygulanan protetik rehabilitasyonun perioral estetik ve dudak hacmi üzerine etkisi incelendiğinde, labiomental kırışıkık dışında değerlendirilen diğer tüm parametrelerde anlamlı bir gelişme gözlendi. Labiomental kırışıklıktaki gelişme istatistiksel olarak anlamlı değildi. Ek olarak, yeniden ölçüm güvenilirliği dört perioral ünitenin tümü için yüksekti $(\geq 0.80$ ) (nazolabial kıvrımlar, ağız köșeleri, labiomental kırışıklık ve üst radyal dudak). Ayrıca tüm korelasyonlar istatistiksel olarak anlamlı idi $(p<0.05)$.

Sonuç: TP ile rehabilitasyon, tam dişsizliğin bir sonucu olarak da görülen perioral birimlerin ve dudak hacminin gelişmesine olumlu katkıda bulunmuştur.

\section{ANAHTAR KELIMELER}

Dişsizlik, Perioral kırışıklıklar, Tam diş protezi, Yüz görünümü

individuals, the prevalence of edentulism is strongly correlated to aging. The rate of edentulism between countries is quite different, and this rate in most countries has been reduced significantly in the past few decades. $^{3,4}$

Ageing of the facial appearance can be occurred the result of degenerative processes such as tooth loss, poor oral hygiene, or improper prosthetic rehabilitation. ${ }^{5}$ Edentulous patients suffer a loss of basic mastication function and the progressive absorption loss of the

\footnotetext{
${ }^{\alpha}$ Private Practice, Selçuklu, Konya, Turkey.

$\beta$ Çanakkale Onsekiz Mart University Faculty of Dentistry, Department of Periodontology, Çanakkale, Turkey

${ }^{\gamma}$ Oral and Dental Health Hospital, Ministry of Health, Kahramanmaraş, Turkey
} 
alveolar bone. Depending on the edentulism and the decrease in the support of the alveolar bone, varying degrees of collapse occur in the facial soft tissues such as shortening in the lower third of the face, deeper wrinkles, prolapse of the labial commissure. ${ }^{6}$

Although dental implants are accepted as the best alternative to the replacement of teeth in most patients, conventional complete dentures (CD) continue to be the primary resource for aesthetic and mastication rehabilitation in edentulous patients for financial reasons, especially in developing countries. ${ }^{7}$ The aesthetic reconstruction of the facial appearance in edentulous patients is one of the most critical goals of CD treatment in prosthodontics. ${ }^{8}$ In this context, facial scales makes possible to comparison of treatment results within the scientific society. ${ }^{9}$

It is believed that facial attractiveness is considerably correlated to increased quality of life and interpersonal success. ${ }^{10}$ Hence, this study aims to evaluate the effect of rehabilitation with removable $C D$ on perioral units in edentulous patients, in line with growing aesthetic demand.

\section{MATERIALS AND METHODS}

The study was approved by the ethics committee of the Faculty of Dentistry at Necmettin Erbakan University (app. no.: 2017/002). A written informed consent was obtained from all participants. They participated in the study by their own wills, and they had the right to withdraw their participation at any time.

The present study consist of 25 individuals referred to the Department of Prosthodontics, Faculty of Dentistry, Necmettin Erbakan University to receive prosthetic treatment based on edentulism were included in the study. In addition to prosthetic treatment, perioral units and lip volume were evaluated for each individual examined by comparing photographs at the beginning and end of the study. None of the patients had perioral tissue disorder or any abnormal condition that could prevent evaluation.

For the evaluation of perioral wrinkles, the scale recommended by Lemperle et al. ${ }^{11}$, where a score of 0 to 5 was given related with the increasing severity. For lip volume, it was ranked in a manner of being scaled between 0 (very thin) and 4 (full) by the lip fullness scale. ${ }^{12}$ The patients were photographed before and after prosthetic rehabilitation to check the perioral soft tissue aesthetics. The parameters analyzed include nazolabial folds, corner of mouths, labiomental crease, upper and lower radial lips, marionette lines and upper and lower lip thickness. To ensure standardization, both frontal and profile photographs were taken by an observer and by stabilizing the camera (Nikon D3100, Nikon Corp., Tokyo, Japan) at a distance of $1 \mathrm{~m}$ from the oral region of the patient.
The photographs were scored, being evaluated by two observers $\left(T_{1}\right)$. To evaluate the repeatability of the scales, measurements were repeated with the same method one month later $\left(\mathrm{T}_{2}\right)$. Disputes in scoring among the observers were agreed with consensus. The data acquired from before and after rehabilitation were recorded on a computer. SPSS 15.0 (SPSS Inc., Chicago, IL, USA) was used for the data entry and analysis. The data obtained before and after the prosthetic rehabilitation were analyzed with the Mann Witney $U$ and Paired Sample T Tests to compare the perioral units. The grading reliability between $T_{1}$ and $T_{2}$ was evaluated using Pearson correlation coefficients. The level of significance was accepted as $p<0.05$.

\section{RESULTS}

All CDs were successfully performed to the patients (Figure 1).

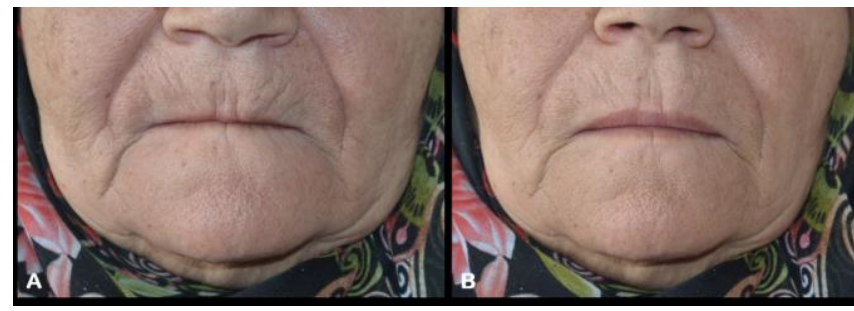

Figure 1

(Changes of perioral units. A) Before Prosthodontic rehabilitation. B) After Prosthodontic rehabilitation.

When the effect of successfully applied prosthetic rehabilitation on perioral aesthetics and lip volume was analyzed in 25 participants; three male and 22 female (61.32 \pm 7.48 years), a significant improvement was observed in all other evaluated parameters except labiomental crease (Table 1). The improvement in the labiomental crease was not statistically significant $(p>$ 0.05) (Figure 2). In addition, re-measurement reliability was high $(\geq 0.80)$ for all four perioral units (nasolabial folds, corners of mouth, labiomental crease and upper radial lip) (Table 2 ). All correlations were statistically significant $(p<0.05)$.

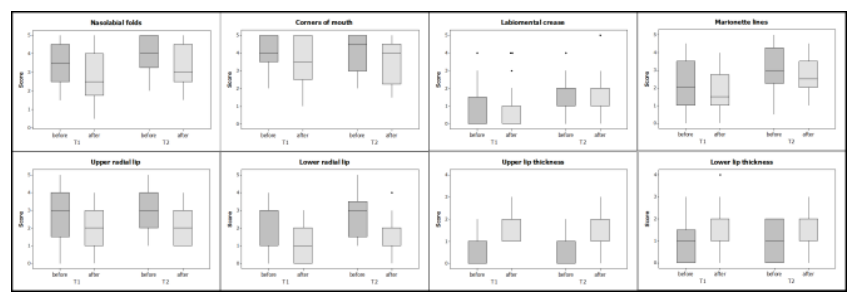

Figure 2

Variation of perioral units associated with prosthodontic rehabilitation at different measurements. 
Table 1.

\section{Statistical findings of the effects of CDs on perioral units}

\begin{tabular}{|c|c|c|}
\hline \multirow[t]{2}{*}{ Perioral Units } & \multicolumn{2}{|c|}{$p$-value } \\
\hline & $\mathbf{T}_{1}$ & $\mathbf{T}_{2}$ \\
\hline Nasolabial folds & 0.000 & 0.000 \\
\hline Corner of mouths & 0.000 & 0.000 \\
\hline Labiomental crease & NS & NS \\
\hline Marionette lines & 0.000 & 0.000 \\
\hline Upper radial lip & 0.000 & 0.000 \\
\hline Lower radial lip & 0.000 & 0.000 \\
\hline Upper lip thickness & 0.000 & 0.000 \\
\hline Lower lip thickness & 0.000 & 0.000 \\
\hline
\end{tabular}

NS, Not significant

Table 2.

\section{Pearson Correlation Coefficients for re- measurement reliability}

\begin{tabular}{|c|c|c|}
\hline \multirow{2}{*}{ Perioral units } & \multicolumn{2}{|c|}{ Prosthodontic rehabilitation } \\
\hline & before & after \\
\hline Nasolabial folds & $0.955^{\star \star \star}$ & $0.907^{\star \star \star}$ \\
\hline Corners of mouth & $0.926^{\star \star \star}$ & $0.937^{\star \star \star}$ \\
\hline Labiomental crease & 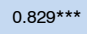 & $0.827^{\star \star \star}$ \\
\hline Marionette lines & $0.774^{\star \star \star}$ & $0.880^{\star \star \star}$ \\
\hline Upper radial lip & $0.867^{\star \star \star}$ & $0.894^{\star \star \star}$ \\
\hline Lower radial lip & $0.579^{\star \star}$ & $0.574^{\star \star}$ \\
\hline Upper lip thickness & $0.700^{* \star \star}$ & $0.668^{* \star \star}$ \\
\hline Lower lip thickness & $0.425^{\star}$ & $0.736^{\star \star \star}$ \\
\hline
\end{tabular}

\section{DISCUSSION}

Seeking for ways to maintain and develop the functional skills of ageing individuals and helping them cope independently in society and ultimately increase their quality of life have become urgent issues with the continued growth of the elderly population in modern societies. ${ }^{13}$ Cooper $^{14}$ emphasized that success is ensured when the therapeutic success is viewed similarly by the clinician and the patient. The present study aimed to eliminate the aesthetic deficiencies caused by edentulism with the personal treatment approach. We concluded that this result was confirmed as a result of the feedback received from patients and that the optimal possible treatment was provided for the patient. Although CD cannot replace natural teeth, it is the basic treatment for edentulous patients and continues to be so..$^{15}$ In addition to conventional prostheses, there are various implant treatment options for the rehabilitation of edentulous patients. The treatment planning process is determined with the age of the patient, psychological requests, aesthetic needs, hygiene requirements, anatomic limitations, the degree of crest resorption, the interocclusal distance, and, finally, treatment costs. Therefore, dental implant treatment is not generalized for the overall edentulous population due to different economic and patient-based reasons, despite the positive outcomes. ${ }^{16}$

Lupi et al. ${ }^{17}$ emphasized the significance of a comprehensive evaluation of the dental status of patients who require to improve the appearance of the perioral tissues. Edentulous patients correlate their aesthetics not only to the appearance of the prosthesis in the mouth but also to the perioral status and general attractiveness of the face. ${ }^{1821}$ For this reason, these restorations, that improve dental and facial appearance, can clearly and positively affect the confidence, socialization, and satisfaction of patients. ${ }^{21} \mathrm{~A}$ study that investigated the effect of implant-supported prosthetic rehabilitation on perioral aesthetics in completely edentulous patients observed a significant improvement in all other parameters except for improvement in Labiomental crease. ${ }^{21}$ In contrast to the implants, similar results were found in the present study evaluating the effect of $C D$ rehabilitation on perioral wrinkles existing in completely edentulous patients.

The ongoing evaluation of the welfare levels of dental patients allows for the verification that the needs of society are met. ${ }^{22}$ The limitation to a single region and the inclusion of a limited sample size are the limitations of this study. In addition, the implantsupported prostheses was not sufficient for economic reasons and could not be included in the study. Thus, there is a need for studies that compare many different treatment methods in numerous individuals.

\section{CONCLUSION}

Within the limitations of the study, rehabilitation with $C D$ contributed positively to the improvement of the perioral wrinkles and lip volume observed as a result of edentulism. In addition, since correlations were observed between measurements performed at different times, the scales in the present study can be confirmed to be effective in evaluating the perioral units. 


\section{REFERENCES}

1. Leveque JL, Goubanova E. Influence of age on the lips and perioral skin. Dermatology 2004;208:307-13.

2. Lopez-Jornet P, Camacho-Alonso F, RodriguezEspin A. Study of lip hydration with application of photoprotective lipstick: influence of skin phototype, size of lips, age, sex and smoking habits. Med Oral Patol Oral Cir Bucal 2010;15:e445-e50.

3. Mojon P. The world without teeth: demographic trends. In: Feine JS, Carlsson GE, eds. Implant overdentures. The standard of care for edentulous patients. Chicago; Quintessence; 2003. p. 3-14.

4. Müller F, Naharro M, Carlsson GE. What are the prevalence and incidence of tooth loss in the adult and elderly population in Europe? Clin Oral Implants Res 2007;18:2-14.

5. Ozturk CN, Ozturk C, Bozkurt M, Uygur HS, Papay FA, Zins JE. Dentition, bone loss, and the aging of the mandible. Aesthet Surg J 2013;33(7):967-74.

6. Feng HL, Xu J. Prosthodontics (ed.2 Feng HL, Xu $J$, et al.) Ch.2, Peking University Medical Press; 2013. p. 41-68.

7. Marchini L. Patients' satisfaction with complete dentures: an update. Braz Dent Sci 2014;17:5-16.

8. Yuan F, Cheng C, Dai N, Sun Y. Prediction of aesthetic reconstruction effects in edentulous patients. Sci Rep 2017;7:18077.

9. Narins RS, Carruthers J, Flynn TC, Geister TL, Goertelmeyer R, Hardas B, et al. Validated assessment scales for the lower face. Dermatol Surg 2012;38:333-42.

10. Langlois J, Kalakanis L, Rubenstein A, Larson A, Hallam M. Maxims or myths of beauty? A metaanalytic and theoretical review. Psychol Bull 2000;126:390-423.

11.Lemperle G, Holmes RE, Cohen SR, Lemperle SM. A classification of facial wrinkles. Plast Reconstr Surg 2001;108:1735-52.

12. Carruthers A, Carruthers J, Hardas B, Kaur M, Goertelmeyer R, Jones $D$, et al. A validated lip fullness grading scale. Dermatol Surg 2008;34:S161-S6.

13.World Health Organization. Aging: Exploding the Myths. Aging and Health Programme. Geneva: WHO,1999.

14. Cooper LF. The current and future treatment of edentulism. J Prosthodont 2009;18:116-22.

15.Carlsson GE, Omar R. The future of complete dentures in oral rehabilitation. A critical review. J Oral Rehabil 2010;37:143-56.

16. Roumanas ED. The social solution-denture esthetics, phonetics, and function. J Prosthodont 2009;18:112-5.

17.Lupi SM, Cislaghi M, Rizzo S, Rodriguez Y Baena R. Rehabilitation with implant-retained removable dentures and its effects on perioral aesthetics: a prospective cohort study. Clin Cosmet Investig Dent 2016;8:105-10.

18.Ide R, Hoshuyama T, Wilson D, Takahashi K, Higashi T. Association of psychological well-being with oral conditions in Japanese workers, J Occup Health 2006;48:487-93.

19. Mehl C, Kern M, Freitag-Wolf S, Wolfart M, Brunzel $S$, Wolfart $S$. Does the oral health impact profile questionnaire measure dental appearance? Int $\mathrm{J}$ Prosthodont 2009;22:87-93.

20.Pan S, Awad M, Thomason JM, Dufresne E, Kobayashi T, Kimoto S, et al. Sex differences in denture satisfaction. J Dent 2008;36:301-8.

21.Davis LG, Ashworth PD, Spriggs LS. Psychological effects of aesthetic dental treatment. J Dent 1998;26:547-54.

22. Castillo-de Oyagüe R, Lynch C, McConnell R, Wilson N. Teaching the placement of posterior resinbased composite restorations in Spanish dental schools. Med Oral Patol Oral Cir Bucal 2012;17:e661-e8.

Corresponding Author:

Hakkı ÇELEBi
Private Practice, Clinic Dent42
Konya, Turkey
Phone : +90 5552992873
E-mail : hake1984@hotmail.com 